Selcuk Journal of Agriculture and Food Sciences

http://sjafs.selcuk.edu.tr/sjafs/index

Research Article

\section{SJAFS}

(2019) 33 (3), 190-193

e-ISSN: 2458-8377

DOI:10.15316/SJAFS.2019.174

\title{
Some Phenotypic Parameters of Marketable Common Carp (Cyprinus Carpio L., 1758) Reared In the Carp Farm Pools in Kirkuk Province of Iraq**
}

\author{
Ahmed Imad MOHAMMED ${ }^{1 *}$, Marwan FADHIL ${ }^{1}$, İbrahim AYTEKIN ${ }^{1}$ \\ ${ }^{1}$ Selcuk University, Faculty of Agriculture, Department of Animal Science, Konya, Turkey
}

\begin{tabular}{l}
\hline ARTICLE INFO \\
\hline Article history: \\
Received date: 22.07 .2019 \\
Accepted date: 29.07.2019 \\
\hline Edited by: \\
Ummuhan Çetin KARACA; Selçuk \\
University, Turkey \\
Reviewed by: \\
Şenol ÇELIK; Bingöl University, Turkey \\
Nazira Mikail MAMMADOVA; Siirt \\
University, Turkey \\
Keywords: \\
Cyprinus carpio \\
Common carp \\
Body measurements \\
Condition factor \\
Phenotypic parameters \\
\hline
\end{tabular}

\section{Introduction}

The food requirement is the outcome of basic needs that human populations needs for living. Considering the fact that 55 percent of the global world population currently consists of urban dwellers, and the rate of increase in the human population considering global climate change, food needs for human will become more important and strategic day after day. Fish is an important component in people's diets, providing about 3.2 billion people with almost 20 percent of their average intake of animal protein. Capture fisheries continue to dominate world output, but aquaculture accounts for a growing percentage of total fish supply. Fishery and aquaculture sectors are particularly important in developing countries, providing both food and livelihoods (FAO 2019). Commercial fishing activities have been implemented for a long time in the lakes, sea and pools. For fishing, lake and sea are an important natural resource for local people and rural settlement in its surrounding. However, fish farming in some regions has been inevitable in order to meet human needs.

Wohlfarth (1984) stated that the common carp is probably the oldest cultured and most domesticated

\footnotetext{
* Corresponding author email: aemad561@yahoo.com

**Short communication
}

fish in the world; they have been farmed for about 4000 years in China and for several hundred years in Europe.

In the world, carp is commercially caught by hunting and also it is also cultivated for commercial purposes such as survival, disease tolerance and resistance to stress or virus (Jeney \& Jeney, 1995; De Boeck et al 2000; Lian \& Sun, 2003; Jeney et al 2009; Falco et al 2012; Hoseinifar et al 2014; Sung et al 2014; KamaliSanzighi et al 2018). Systematic crossbreeding has been performed only among common carp varieties, since the other cyprinids are devoid of distinct strains or varieties. (Hulata 1995). A feature of the carp, which has economic importance in the temperate climatic zones, is that it can live in both hot water and cold water. The homeland of the carp is spread over a wide area starting from Anatolia to South Japan (FAO 2018). There are different varieties of cultured carps in the world. According to their distribution areas, cultured carp includes seven primary species such as the common carp, the grass carp, the silver carp, the bighead carp (Chinese carps), the catla carp, the rohu carp and the mrigal carp (Indian major carps). Carp farming in the world varies depending on the consumption habits of people or satisfying the needs of the people through hunting. 
Common carps grown in pools in Kirkuk district of Iraq are an important source of animal protein for the people of the region. Briefly, common carps play an important role as agricultural products in Kirkuk economy today. The aim of this study was to determine the phenotypic parameters of some body measurements in common carp (Cyprinus carpio L., 1758) reared in pools in Kirkuk province of Iraq.

\section{Materials and Methods}

Cyprinus carpio samples in four carp farm pools were reared in concrete basins of $15 \times 20 \times 2$ meter for 180 days. Fish were fed on commercial diet containing $21.1 \%$ proteins, $3.7 \%$ fats, $5.3 \%$ cellulose and 3200 $\mathrm{kcal} / \mathrm{kg}$ metobolic energy. A total of 100 male and females common carp reared in fish pools were caught to determine some body measurements before pre-sales to consumers in this study. Some body measurements such as body weight (BW), total length (TL), body depth (BD) and fork length (FL) were taken from each common carps. From the body measurements, the length and depth measurements were obtained using a measuring tape with a sensitivity of $1 \mathrm{~mm}$ and weight

Table 1

Statistical analysis and descriptive statistics of some body measurements in common carp (Cyprinus carpio L., 1758)

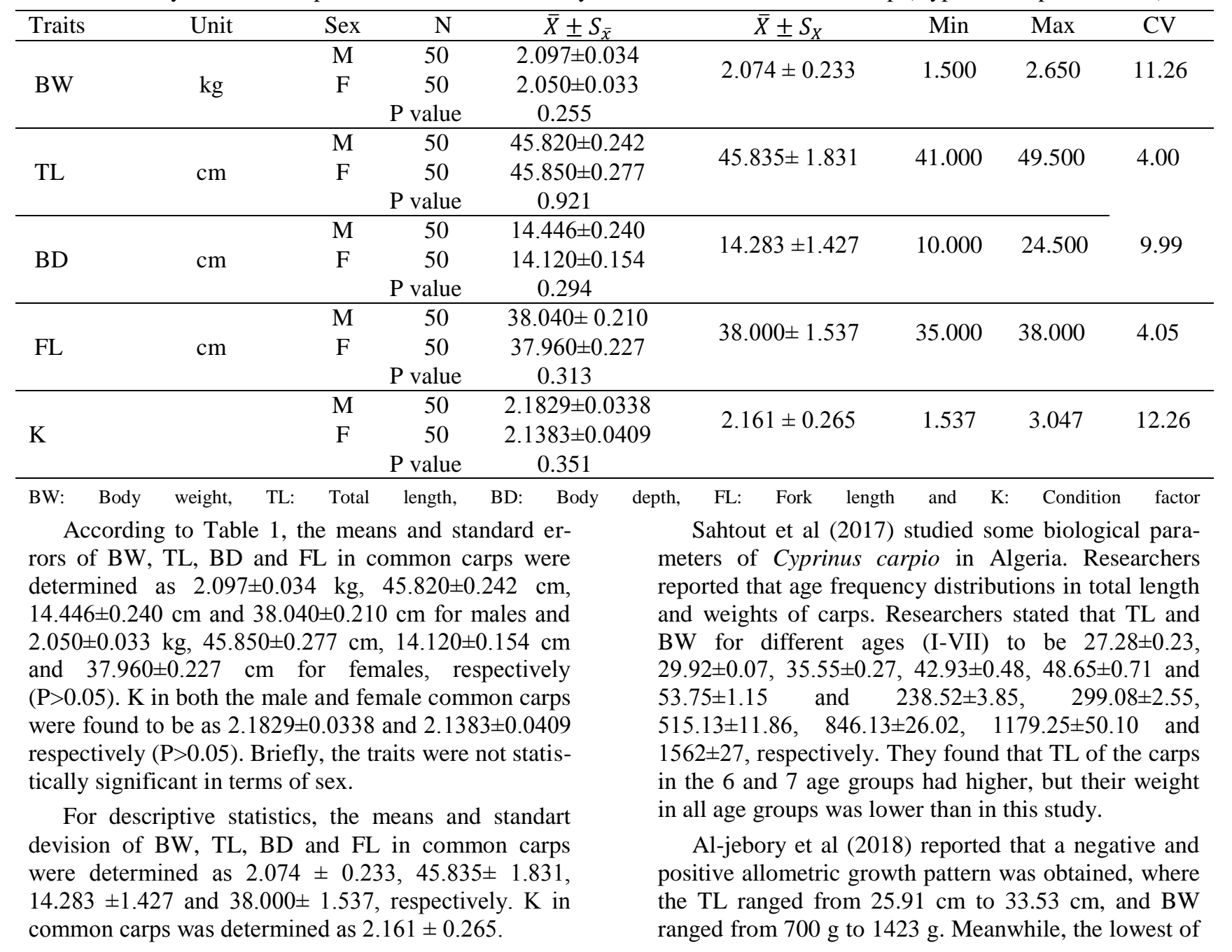

measurements were obtained with a digital weight scale with a sensitivity of $1 \mathrm{~g}$. factor $(\mathrm{K})$ is used as an important criterion since it contains both live weight and total length. Therefore, these properties are used in decision making in marketable aquaculture products suitable for human consumption. Fulton's condition factor $(\mathrm{K})$ was calculated as reported by Nash et al (2006).

$$
\mathrm{K}=100 \mathrm{BWxBL}-3
$$

Statistical analysis of some body measurements via sex were calculated by using the independent samples t-test, and descriptive statistics of some body measurements with the MINITAB statistical package program (Minitab 2010).

\section{Results and Discussion}

Descriptive statistics with regard to some body measurements in common carp (Cyprinus carpio L., 1758) were given in Table 1 . Table 1 show that somebody measurements such as BW, TL, BD, FL and K in both the male and female common carps.
As one of the population parameters, the condition
According to Table 1, the means and standard errors of BW, TL, BD and FL in common carps were and $37.960=0.227 \mathrm{~cm}$ for femas, respectively $(\mathrm{P}>0.05) . \mathrm{K}$ in both the male and female common carps were found to be as $2.1829 \pm 0.0338$ and $2.1383 \pm 0.0409$ not statis-

fevision of BW, TL, BD and FL in common carps were determined as $2.074 \pm 0.233,45.835 \pm 1.831$, common carps was determined as $2.161 \pm 0.265$. ranged from $700 \mathrm{~g}$ to $1423 \mathrm{~g}$. Meanwhile, the lowest of 
1.03 and highest of 3.54 in "b" value that is the length exponent or slope in the equation of length-weight relationships for weight was recorded in group F (AlMuthanna) and group C (Karbala), respectively. Therefore, Fulton condition factor $(\mathrm{K})$ range from 2.57 to 4.94. While, relative condition factor $(\mathrm{K})$ was in the ranged of 0.95 to 1.01 . A linear relationship between TL and standard length (SL) among the provinces for

Table 2

Differences between the province in TL, BW and K (Al-jebory et al 2018)

\begin{tabular}{lcccccc}
\hline \multirow{2}{*}{ Province } & \multicolumn{2}{c}{ TL $(\mathrm{cm})$} & \multicolumn{2}{c}{ BW $(\mathrm{g})$} & \multirow{2}{*}{ K } & \multirow{2}{*}{ SD of K } \\
\cline { 2 - 5 } & Min & Max & Min & Max & & \\
\hline Baghdad & 26.60 & 29.70 & 890 & 1423 & 4.94 & 0.53 \\
Babil & 26.36 & 29.88 & 820 & 1120 & 4.41 & 0.45 \\
Karbala & 26.21 & 28.45 & 700 & 1010 & 4.29 & 0.56 \\
Al-Najaf & 25.91 & 28.92 & 790 & 1090 & 4.61 & 0.32 \\
Dhi Qar & 28.90 & 33.50 & 770 & 990 & 2.66 & 0.28 \\
Al-Muthanna & 29.13 & 33.53 & 727 & 925 & 2.57 & 0.27 \\
Al-Basrah & 25.60 & 30.30 & 800 & 1080 & 4.38 & 0.41 \\
\hline
\end{tabular}

BW: Body weight, TL: Total length and K: Condition factor

Considering the total length and body weight in Table 2, these traits in this study were found higher than reported by Al-jebory et al (2018).But, condition factors in this study were lower than in all provinces reported by Al-jebory et al (2018). Also, researchers stated that the factors affecting the variation values of $\mathrm{K}$ may include sex, stages of maturity, and state of stomach contents.

Fishery resources are an important source of proteins, vitamins and micronutrients that are not available in such quantity and diversity either in cropsor in other animal products (Lauria et al 2018). Fish consumption varies substantially from country to country depending on local traditions. Fish populations that live in inland waters and commercial pools is vital for human consumption as a source of animal protein. The common carp can be grown more easily than other fish in pools, especially in case of failure to adapt to climate change in ecological environments in inland waters. Considering the adaptability of carp compared to other fish, with this perspective, carp can be an indispensable species of fish in the future. In short, it is important to monitor growth and development of carp in both ecological and commercial environments. Body measurements discussed in this study such as body weight, total.

\section{References}

Al-Jebory TA, Das SK, Usup G, Bakar Y, Al-Saadi AH (2018). Length-weight and length-length relationships of common carp (Cyprinus carpio L.) in the middle and southern Iraq provinces. In AIP Conference Proceedings (Vol. 1940, No. 1, p. 020025), AIP Publishing.

De Boeck G, Vlaeminck A, Van der Linden A, Blust R (2000). Salt stress and resistance to hypoxic fish groups were obtained. The variances in " $b$ " value ranged from 0.10 to 0.93 with the coefficient of correlation of 0.02 to 0.97 . In addition these researchers stated that these results will serve as a guide in ecological and biological study of common carp (Cyprinus carpio L. 1758) in the middle and Southern Iraq provinces and environs. Table 2 showed differences between province in $\mathrm{TL}, \mathrm{BW}$ and $\mathrm{K}$. 
Kamali-Sanzighi M, Akrami R, Ghelichi A, Shamloofar M (2018). Partial Replacement of Plant Sources by Waste Date (Phoneix Dactylifera) in the Diet of Fingerling Common Carp (Cyprinus carpio) on Growth Performance, Feed Utilization, Hematological Parameters and Resistance to Stress. Turkish Journal of Fisheries and Aquatic Sciences, 19 (9), 775-784.

Lauria V, Das I, Hazra S, Cazcarro I, Arto I, Kay S, Ofori-Danson P, Ahmed M, Hossain MAR, ManuelBarange M, Fernandes JA (2018). Importance of fisheries for food security across three climate change vulnerable deltas. Science of The Total Environment, 640, 1566-1577.

Liang LQ, Sun XW (2003). Mapping cold tolerance strain on genetic linkage map of common carp [J]. Journal of Dalian Fisheries University, 4.

Minitab (2010). Minitab 16.1.1 for Windows. State College, PA, USA: Minitab Inc.
Sahtout F, Boualleg C, Naima K, Kaouachi N, Boufekane B (2017). Study of some biological parameters of Cyprinus carpio from Foum Elkhanga Dam, Souk-Ahras, Algeria. ACL Bioflux, http://www. bioflux. com. ro/aacl, 10(4).

Sung YY, Liew HJ, Ambok Bolong AM, Abdul Wahid ME, MacRae TH (2014). The induction of Hsp70 synthesis by non- lethal heat shock confers thermotolerance and resistance to lethal ammonia stress in the common carp, Cyprinus carpio (Linn). Aquaculture research, 45 (10), 1706-1712.

Nash RD, Valencia AH, Geffen AJ (2006). The origin of Fulton's condition factor-setting the record straight. Fisheries, 31 (5), 236-238.

Wohlfarth GW (1984). Common carp. In: L. Mason (Editor), Evolution of Domesticated Animals. Longman, Harlow, UK, pp. 375-380. 